\title{
CHEMICAL COMPOSITION AND ANTIFUNGAL ACTIVITY OF HYPTIS SUAVEOLENS (L.) POIT LEAVES ESSENTIAL OIL AGAINST ASPERGILLUS SPECIES
}

\section{Ana Carolina Pessoa Moreira ${ }^{1}$; Edeltrudes de Oliveira Lima ${ }^{2}$; Paulo Alves Wanderley ${ }^{3}$; Egberto Santos Carmo ${ }^{1}$; Evandro Leite de Souza ${ }^{4 *}$}

${ }^{1}$ Laboratório de Tecnologia Farmacêutica, Universidade Federal da Paraíba, João Pessoa, PB, Brasil; ${ }^{2}$ Laboratório de Micologia, Departamento de Ciências Farmacêuticas, Centro de Ciências da Saúde Universidade Federal da Paraíba, João Pessoa, PB, Brasil;

${ }^{3}$ Departamento de Agricultura, Centro de Formação de Tecnólogos, Universidade Federal da Paraíba, Bananeiras, PB, Brasil; ${ }^{4}$ Laboratório de Microbiologia de Alimentos, Departamento de Nutrição, Centro de Ciências da Saúde, Universidade Federal da Paraíba, João Pessoa, PB, Brasil.

Submitted: November 27, 2008; Returned to authors for corrections: June 23, 2009; Approved: August 22, 2009.

\begin{abstract}
This study aimed to identify the constituents of the essential oil from Hyptis suaveolens (L.) leaves using a Gas Chromatograph - Mass Spectrometer and assess its inhibitory effect on some potentially pathogenic Aspergilli (A. flavus, A. parasiticus, A. ochraceus, A. fumigatus and A. niger). Eucaliptol (47.64\%) was the most abundant component in the oil, followed for gama-ellemene $(8.15 \%)$, beta-pynene $(6.55 \%),(+)$ 3-carene $(5.16 \%)$, trans-beta-cariophyllene $(4.69 \%)$ and germacrene $(4.86 \%)$. The essential oil revealed an interesting anti-Aspergillus property characterized by a Minimum Inhibitory Concentration and Minimum Fungicidal Concentration of 40 and $80 \mu \mathrm{L} / \mathrm{mL}$, respectively. The oil at 80 and $40 \mu \mathrm{L} / \mathrm{mL}$ strongly inhibited the mycelial growth of A. fumigatus and A. parasiticus along 14 days. In addition, at 10 and $20 \mu \mathrm{L} / \mathrm{mL}$ the oil was able to cause morphological changes in A. flavus as decreased conidiation, leakage of cytoplasm, loss of pigmentation and disrupted cell structure suggesting fungal wall degeneration. These findings showed the interesting anti-Aspergillus property of $H$. suaveolens leaves essential oil supporting its possible rational use as alternative source of new antifungal compounds to be applied in the aspergillosis treatment.
\end{abstract}

Key words: Hyptis suaveolens L. (Poit), essential oil, anti-Aspergillus effect.

\section{INTRODUCTION}

Human aspergillosis is an opportunistic infection related to the inhalation of Aspergillus conidia, colonization of wounds and/or penetration in human tissues through surgical incision. Cutaneous aspergillosis, aspergillar otomycosis, aspergillar onychomycosis, invasive lung aspergillosis, aspergillar sinusitis and aspergilloma are some clinical manifestations of this infection (9). Resistance of Aspergillus strains to some clinically used antifungals is a major problem making to rise up a search for compounds more effective and with minimum side effects $(5,6)$.

\footnotetext{
*Corresponding Author. Mailing address: Laboratório de Microbiologia de Alimentos, Departamento de Nutrição, Centro de Ciências da Saúde, Universidade Federal da Paraíba, João Pessoa, Paraíba, Brasil.; Tel.: 8332167499 Fax: 83 32167499.; Email: evandroleitesouza@ccs.ufpb.br
} 
Recently the antimicrobial potential of essential oils has been of great interest in both academia and pharmaceutical industry since their possible use as alternative anti-infective agents emerged from a growing tendency to decrease the use of synthetic antibiotics in clinical therapy $(15,20)$.

Hyptis suaveolens (L.) Poit. (Lamiaceae), popularly known in Brazil for "alfazema", is a fast-growing perennial herb found in dense clumps along roadsides, in over-grazed pastures and around stockyards in the tropics. Its branched, semi-woody stems can reach a height of $2 \mathrm{~m}$, and the plant gives off a characteristic minty smell when crushed (21). Originally native to tropical America, it is now considered a weed worldwide (4).

H. suaveolens is popularly used in the treatment of respiratory and gastrointestinal infections, indigestion, colds, pain, fever, cramps and skin diseases $(3,16)$. The leaves are used as anticancer and antifertility (in females) agent, while their aqueous extract has showed an antinociceptive effect and acute toxicity (21). To date, although few reports $(11,27)$ have found antibacterial and antifungal properties of $H$. suaveolens essential oil there has been a lack of studies emphasizing its anti-Aspergillus activity.

This study aimed to analyze the chemical composition of the essential oil obtained from $H$. suaveolens leaves and assess its inhibitory effect on the growth and morphogenesis of potentially pathogenic Aspergilli.

\section{MATERIAL AND METHODS}

\section{Plant}

Leaves of $H$. suaveolens L. (Poit) were collected in January of 2007 from the Experimental Plant Collection, Department of Agriculture, Center of Technologists Formation, Federal University of Paraíba, Bananeiras, Brazil. The plant was authenticated by the National Herbarium Prof. Jaime Coelho de Moraes (Areia, Brazil) where a voucher specimen was deposited under a number 11367. H. suaveolens essential oil was obtained by hydrodistillation using a Clevenger apparatus. The oil was assayed in a range of $20-$
$0.5 \mu \mathrm{L} . \mathrm{mL}^{-1}$, and the solutions were prepared in sterile distilled water added of bacteriological agar $(0.15 \mathrm{~g} / 100 \mathrm{~mL})$ as stabilizing agent (25).

\section{Tested microorganisms}

Aspergillus parasiticus ATCC-15517, A. flavus ATCC16013, A. fumigatus ATCC-40640, A. ochraceus ATCC-22947 and A. niger ATCC-1004 were used as test microorganisms. Stock cultures were kept on sterile Sabouraud agar (SA) slants under $7{ }^{\circ} \mathrm{C}\left( \pm 1{ }^{\circ} \mathrm{C}\right)$. For preparing the inocula used in antimould assays were used 7 days-old cultures grown on sterile $\mathrm{SA}$ at $25-28{ }^{\circ} \mathrm{C}$. After the incubation period, the mould spores were taken by adding sterile $\mathrm{NaCl}(0.85 \mathrm{~g} / 100 \mathrm{~mL})$ on the growth media followed for gentle shaking for $30 \mathrm{~s}$. The obtained suspensions were filtered through sterile triple layer cheesecloth to remove mycelial fragments. Mould spores was counted using hemocytometer. Spores suspensions were adjusted by serial dilutions using sterile $\mathrm{NaCl}(0.85 \mathrm{~g} / 100 \mathrm{~mL})$ to contain approximately $10^{6}$ spores/mL (19).

\section{Essential oil chemical analysis}

Essential oil chemical composition was analyzed using a gas chromatograph (GC) fitted to a mass spectrometer (MS) (GC-MS, Shimadzu QP-5000, Kyoto, Japan) operating in electron-impact (70 eV, m/z 40 - 550) mode; the fused-silica capillary column used was an OV-5 with diameter of $30 \mathrm{~m}$ long., $0.25 \mathrm{~mm}$ i.d., $0.25 \mu \mathrm{m}$ film thickness (Ohio Valley Special Chemical Inc., USA). The chromatographic conditions were as follow: sample preparation $1 \mu \mathrm{L}$ in $1 \mathrm{~mL}$ of hexane; injection volume $1 \mu \mathrm{L}$; split ratio 1:20; helium flow rate 0.9 $\mathrm{mL} / \mathrm{min}$; temperature programme ramp from $60{ }^{\circ} \mathrm{C}$ to $240{ }^{\circ} \mathrm{C}$ with a gradient of $3{ }^{\circ} \mathrm{C} / \mathrm{min}$ (holding the initial and final temperature for $10 \mathrm{~min}$ ); injector temperature $230{ }^{\circ} \mathrm{C}$; detector temperature $280{ }^{\circ} \mathrm{C}$. The identification of the essential oil components was performed by retention indexes (1) and comparing their mass spectra with a data bank (System GCMS, Nist. 62 lib) and literature (1, 14). Retention indexes were obtained by co-injection with a hydrocarbons $\left(\mathrm{C}_{9}-\mathrm{C}_{24}\right)$ standard mixture using the Van Den Doll equation (26). 
Determination of Minimum Inhibitory Concentration (MIC) and Minimum Fungicidal Concentration (MFC)

MIC and MFC was determined by macrodilution in broth. For this, $5 \mathrm{~mL}$ of double strength Sabouraud broth was inoculated with $1 \mathrm{~mL}$ of the mould suspension. After that, 4 $\mathrm{mL}$ of the essential oil solution with different concentrations was added to the system and followed by shaking for $30 \mathrm{~s}$ using Vortex. The system was incubated for $72 \mathrm{~h}$ at $25-28{ }^{\circ} \mathrm{C}$ without shaking. MIC was defined as the lowest concentration of the essential oil required to completely prevent visible fungal growth. An aliquot $(1 \mathrm{~mL})$ of the tubes showing no growth was subcultured on sterile SA Petri dishes at $25-28$ ${ }^{\circ} \mathrm{C}$ for $72 \mathrm{~h}$ to determine if the inhibition was reversible or permanent. MFC was defined as the lowest concentration of the oil at which no growth was noted on SA $(19,23)$. Control flasks without essential oil were tested in the same way.

\section{Measure of radial mycelial growth}

Inhibition of the essential oil $(20,40$ e $80 \mu \mathrm{L} / \mathrm{mL})$ on the radial mycelial growth of $A$. parasiticus ATCC-15517 and $A$. fumigatus ATCC 40640 was determined using the poisoned substrate technique (dilution in solid medium). For this, a 2 $\mathrm{mm}$ plug taken from a 10 days-old mould culture grown on SA slants at $25-28{ }^{\circ} \mathrm{C}$ were placed on the center of sterile SA Petri dishes added of $2.5,1.25$ and $0.6 \mu \mathrm{L} / \mathrm{mL}$ of the oil. At different intervals $(0,2,4,6,8,10,12$ and 14 days) after incubation at $25-28{ }^{\circ} \mathrm{C}$, the radial mycelial growth was measured (mm) using calipers (7). Growth media without essential oil was tested in the same way.

\section{Fungal morphogenesis study}

For evaluating morphological alterations caused by the essential oil (10 and $20 \mu \mathrm{L} / \mathrm{mL}$ ) in A. flavus ATCC-16013, a sample of mycelium was taken from the periphery of a 10days-old fungal colony grown on SA containing the essential oil at $25-28{ }^{\circ} \mathrm{C}$. The samples were fixed in lacto-phenol-cotton blue stain and observed under the microscope at $400 \mathrm{x}$ to examine morphological abnormalities. Samples from control
SA plates without adding the essential oil were also stained and their morphological aspects were observed (22).

\section{RESULTS AND DISCUSSION}

The compounds identified in the essential oil of $H$. suaveolens leaves are listed in Table 1. GC-MS resulted in the identification of 26 compounds making $100 \%$ of the oil. The terpene alcohol eucaliptol (47.64\%) was the most abundant compound, followed for the terpene hydrocarbons gamaellemene $(8.15 \%)$, beta-pynene $(6.55 \%),(+)$-3-carene $(5.16$ $\%)$, trans-beta-cariophyllene $(4.69 \%)$ and germacrene $(4.86$ $\%)$. In this regard, trans-beta-caryophyllene has been reported to occur abundantly in $H$. suaveolens leaves essential oil $(8,12$, 23). Compounds frequently found in the essential oil, such as 1,8 -cineole $(2,4,8)$, germacrene D and germacrene B $(10,17)$ were not found suggesting that the assayed essential oil could correspond to a new chemotype.

H. suaveolens leaves essential oil showed broad spectrum activity against Aspergilus species here studied. MIC and MFC were 40 and $80 \mu \mathrm{L} / \mathrm{mL}$, respectively (data not showed). Malele et al. (12) reported a strong antifungal activity for the oil of $H$. suaveolens leaves at 500 and $1000 \mu \mathrm{g} / \mathrm{mL}$ against Saccharomyces cerevisiae, Mucor sp. and Fusarium moniliforme, whereas Asekun et al. (3) reported that the oil of $H$. suaveolens leaves $(5 \mathrm{mg} / \mathrm{L})$ displayed significant inhibitory activity against gram-positive (Staphylococcus aureus and Bacillus cereus) and gram-negative (Escherichia coli and Pseudomonas aeruginosa) bacteria and yeast (Candida albicans).

Effect of $H$. suaveolens leaves essential oil on the radial mycelial growth of A. fumigatus ATCC-40640 and A. parasiticus ATCC-15517 in solid medium is showed in Table 2 and 3. The essential oil at 40 and $80 \mu \mathrm{L} / \mathrm{mL}$ exhibited a fast and steady rate of mycelial growth inhibition of both fungi. $H$. suaveolens oil at 40 and $80 \mu \mathrm{L} / \mathrm{mL}$ provided a $100 \%$ of lethal effect against $A$. parasiticus and A. fumigatus along 14 days of exposure. The fungi presented a light increase in the radial growth along the period of exposure to $20 \mu \mathrm{L} / \mathrm{mL}$ of the oil. 
Table 1. GC-MS analysis of the essential oil from H. suaveolens L. (Poit) (results expressed in percent of oil total mass).

\begin{tabular}{|c|c|c|c|}
\hline Peaks & Retention time (min) & Compound & Peak area (relative \%) \\
\hline 1 & 5.691 & cys-ocymene & 3.56 \\
\hline 2 & 6.783 & sabynene & 2.52 \\
\hline 3 & 6.925 & beta-pynene & 6.55 \\
\hline 4 & 7.017 & 1-octen-3-ol & 0.28 \\
\hline 5 & 7.227 & beta-myrcene & 1.83 \\
\hline 6 & 7.922 & $(+)$-3-carene & 5.16 \\
\hline 7 & 8.867 & eucaliptol & 47.64 \\
\hline 8 & 9.588 & gama-terpynene & 0.77 \\
\hline 9 & 10.675 & terpinalene & 0.60 \\
\hline 10 & 11.092 & linalool & 0.38 \\
\hline 11 & 11.642 & (+)-fenchole & 0.29 \\
\hline 12 & 13.245 & citronelal & 1.10 \\
\hline 13 & 13.841 & alpha-terpineol & 0.57 \\
\hline 14 & 14.300 & 4-terpineol & 0.57 \\
\hline 15 & 14.875 & linalil propyanate & 0.55 \\
\hline 16 & 16.555 & citronelol & 1.46 \\
\hline 17 & 77.723 & geraniole & 1.54 \\
\hline 18 & 23.419 & beta-bourbonene & 0.83 \\
\hline 19 & 23.736 & beta-ellemene & 0.57 \\
\hline 20 & 25.007 & trans-beta-cariophyllene & 4.69 \\
\hline 21 & 27.629 & germacrene & 4.86 \\
\hline 22 & 28.168 & bicyclogermacrene & 2.44 \\
\hline 23 & 28.357 & gama-ellemene & 8.15 \\
\hline 24 & 29.298 & delta-cedinene & 1.28 \\
\hline 25 & 30.329 & elemol & 0.84 \\
\hline 26 & 31.505 & espatulenol & 0.95 \\
\hline
\end{tabular}

Table 2. Effect of the essential oil from Hyptis suaveolens L. (Poit) on the mycelia radial growth of A. fumigatus ATCC-40640 (results expressed as inhibition percent of the mycelial radial growth in relation to the control assay).

\begin{tabular}{ccccccccc}
\hline $\begin{array}{c}\text { Essential oil } \\
(\boldsymbol{\mu L} / \mathbf{m L})\end{array}$ & $\mathbf{1}$ & $\mathbf{2}$ & $\mathbf{4}$ & $\mathbf{6}$ & $\mathbf{8}$ & $\mathbf{1 0}$ & $\mathbf{1 2}$ & $\mathbf{1 4}$ \\
\cline { 2 - 10 } & $78 \%$ & $49 \%$ & $45 \%$ & $60 \%$ & $76 \%$ & $85 \%$ & $94 \%$ & $94 \%$ \\
40 & $100 \%$ & $100 \%$ & $100 \%$ & $100 \%$ & $100 \%$ & $100 \%$ & $100 \%$ & $100 \%$ \\
80 & $100 \%$ & $100 \%$ & $100 \%$ & $100 \%$ & $100 \%$ & $100 \%$ & $100 \%$ & $100 \%$ \\
\hline
\end{tabular}

Table 3. Effect of the essential oil from Hyptis suaveolens L. (Poit) on the mycelia radial growth of A. parasiticus ATCC-15517 (results expressed as inhibition percent of the mycelial radial growth in relation to the control assay).

\begin{tabular}{ccccccccc}
\hline $\begin{array}{c}\text { Essential oil } \\
(\boldsymbol{\mu} \mathbf{L} / \mathbf{m L})\end{array}$ & $\mathbf{1}$ & $\mathbf{2}$ & $\mathbf{4}$ & $\mathbf{6}$ & $\mathbf{8}$ & $\mathbf{1 0}$ & $\mathbf{1 2}$ & $\mathbf{1 4}$ \\
\cline { 2 - 9 } & $50 \%$ & $47 \%$ & $48 \%$ & $41 \%$ & $46 \%$ & $67 \%$ & $78 \%$ & $75 \%$ \\
40 & $100 \%$ & $100 \%$ & $100 \%$ & $100 \%$ & $100 \%$ & $100 \%$ & $100 \%$ & $100 \%$ \\
80 & $100 \%$ & $100 \%$ & $100 \%$ & $100 \%$ & $100 \%$ & $100 \%$ & $100 \%$ & $100 \%$ \\
\hline
\end{tabular}


Observations of A. flavus ATCC-16013 under the light microscope at $400 \mathrm{x}$ magnification after exposure to 10 and 20 $\mu \mathrm{L} / \mathrm{mL}$ of $H$. suaveolens essential oil showed some morphological abnormalities (Figure 1). Microscopic examination of the control mycelium (untreated cell) showed regular growing hyphae with homogenous cytoplasm and visible profuse conidiation on a large conidial head (Figure
1A-B). The mycelia cultivated in the medium added of the oil appeared to present morphological changes with an anomalous heterogeneous mycelial structure. The alterations included lack of sporulation, loss of cytoplasm content, loss of pigmentation, distorted development of hyphae. The hyphae become distorted with swelling along its structure and budded apical tips (Figure 1C-D-E).

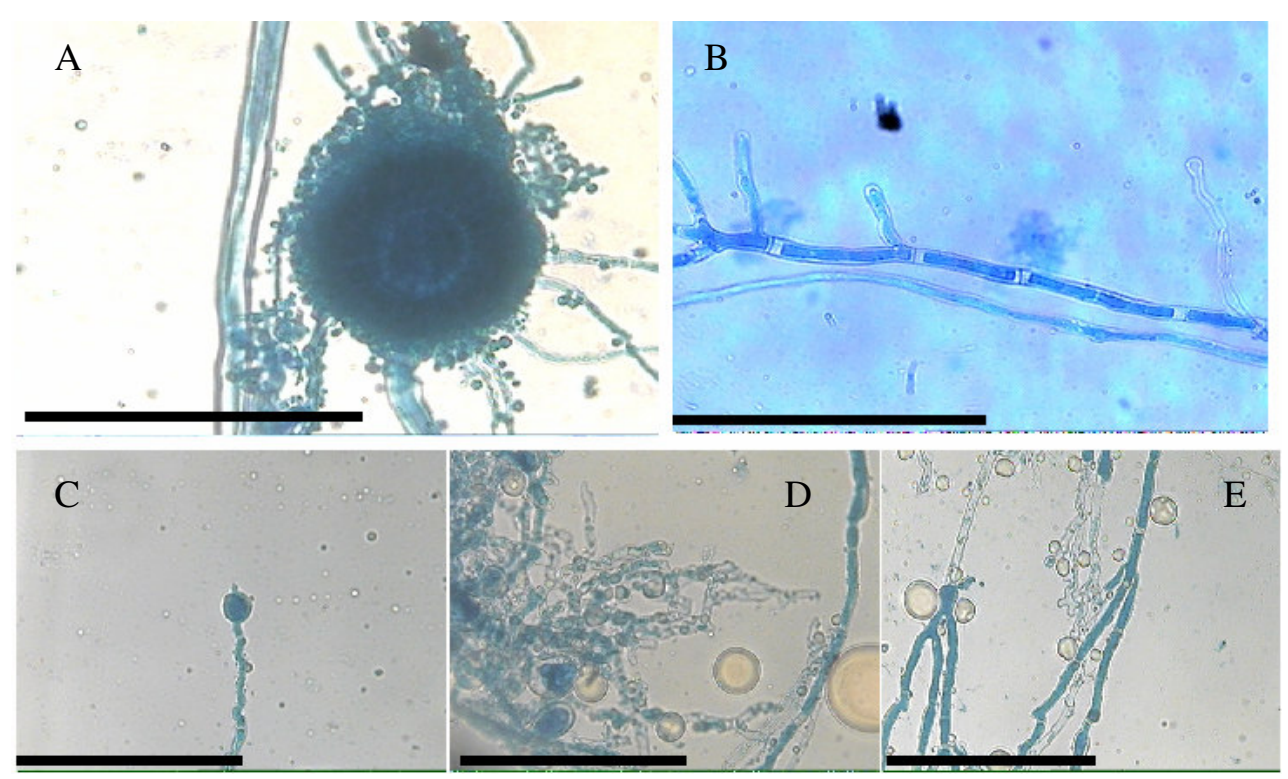

Figure 1. Light microphotographs of A. flavus ATCC-16013 mycelium growing on AS without or with H. suaveolens essential oil (20 $\mu \mathrm{L} / \mathrm{mL}$ ) during 7 days of incubation at $25-28^{\circ} \mathrm{C}$. (A) Control conidial head of A. flavus, large and radiated, development of vesicle on conidiophore, conidia clearly visible, Bar $100 \mu \mathrm{m}$. (B) control magnification of single vegetative hyphae of A. flavus, regular growing hyphae, clear visualization of a homogenous cytoplasm and homogeneous structure, Bar $100 \mu \mathrm{m}$. (C) Modifications of the conidial head of A. flavus induced by $20 \mu \mathrm{L} / \mathrm{mL}$ of H. suaveolens essential oil, showing clear reduction in conidiation, Bar $100 \mu \mathrm{m}$. (D-E) Hyphae with loss of pigmentation conidiation, anomalous structure, clear leakage of cytoplasm content and destruction of cell structure noted by disrupted hyphae integrity induced by $10 \mu \mathrm{L} / \mathrm{mL}$ of $H$. suaveolens essential oil, Bar $100 \mu \mathrm{m}$.

Although we have found no report about the effect of $H$. suaveolens essential oil on the morphogenesis of moulds some researchers state that essential oils caused morphological changes as lack of sporulation, loss of pigmentation, aberrant development of conidiophores (flattened and squashed) and distortion of hyphaes in Aspergillus species (13, 18, 22).Regarding these findings the authors purposed that the anti-Aspergillus activity of the assayed essential oils probably included an attack on the cell wall and retraction of the cytoplasm in the hyphae ultimately resulting in death of mycelium.

These results confirmed the efficacy of $H$. suaveolens leaves essential oil to inhibit the growth of some potentially pathogenic Aspergilli on the base of MIC, MBC, mycelia growth and morphological changes. Regarding our results, the essential oil showed a strong antifungal property, supporting its possible use as a therapeutic alternative for the treatment of infections caused by Aspergillus species. 


\section{REFERENCES}

1. Adams, R.P. (1995). Identification of essential oil components by gas chromatography/mass spectroscopy. Carol Stream: Allured Publishing Corporation.

2. Ahmed, M.; Scora, R.W.; Ting, I.P. (1994). Composition of leaf oil of Hyptis suaveolens (L.) Poit. J. Essent. Oil Res., 6: 571-575.

3. Asekun, O.T.; Ekundayo, O.; Adeniyi, B.A. (1999). Antimicrobial activity of the essential oil of Hyptis suaveolens leaves. Fitoterapia, 70: 440-442.

4. Azevedo, N.R.; Campos, I.F.P.; Ferreira, H.D.; Portes, T.A.; Santos, S.C.; Seraphin, J.C.; Paula, J.R.; Ferri, P.H. (2001). Chemical variability in the essential oil of Hyptis suaveolens. Phytochem., 57: 733-736.

5. Canuto, M.M.; Rodero, F.G. (2002). Antifungal drug resistance to azoles and polyenes. Lancet Infect. Dis., 2: 550-563.

6. Curtis, L.; Conroy, L.; Coli, S.; Baker, K.; Our, C.H.; Hershow, R.; Norlock-Cruz, F.; Scheff, P. (2005). Aspergillus surveillance project at a large tertiary-care hospital. J. Hosp. Infect., 59: 188-196.

7. Daferera, D.J.; Ziogas, B.N.; Polissiou, M.G. (2003). The effectiveness of plant essential oils on the growth of Botrytis cinerea, Fusarium sp. and Clavicbacter michiganensis subsp. michiganensis. Crop Prot., 22: $39-44$.

8. Din, L.B.; Zakaria, Z.; Samsudin, M.W.; Brophy, M.; Toia, R.F. (1988). Composition of the steam volatile oil from Hyptis suaveolens Poit. Pertanika, 11: 239-242.

9. Dubey, A.; Patwardhan, R.V.; Sampth, S.; Santoshi, V.; Kolluri, S.; Nanda, A. (2006). Intracranial fungal granuloma: analysis of 40 patients and review of the literature. Surg. Neurol., 63: 254-260.

10. Fun, C.E.; Svendsen, A.B. (1990). The essential oil of Hyptis suaveolens Poit. grown on Aruba. Flav Fragr J 5: 161-163.

11. Jain, S.R.; Jain, P.R.; Jain, M.R. (1974). Antibacterial evaluation of some indigenous volatile oils. Planta Med., 26: 196-199.

12. Malele, R.S.; Mutayabarwa, C.K.; Mwangi, J.W.; Thoithi, G.N.; Lopez, A.G.; Lucini, E.I.; Zygadlo, J.A. (2003). Essential Oil of Hyptis suaveolens (L.) Poit. from Tanzania: composition and antifungal activity. J. Essent. Oil Res., 15: 438-440.

13. Mares, D.; Tosi, B.; Poli, F.; Andreotti, E.; Romangnoli, C. (2004). Antifungal activity of Tagetus patula on some phytopatogheni fungi ultraestructural evidence on phythum ultimum. Microbiol. Res., 859: 295304.

14. McLafferty, F.W.; Stauffer, D. (1989). The Wiley/NBS Registry of Mass Spectral Data. New York: John Wiley Sons.

15. Nakamura, C.V.; Ishida, K.; Faccin, L.C.; Dias Filho, B.P.; Cortez, A.A.G.; Rozental, S.; de Souza, W.; Ueda-Nakamura, T. (2004). In vitro activity of essential oil from Ocimum gratissimum L. against four Candida species. Res. Microbiol., 155: 579-586.
16. Oliveira, M.J.; Campos, I.F.P.; Oliveira, C.B.A.; Santos, M.R.; Souza, P.S.; Santos, S.C.; Seraphin, J.C.; Ferri, P.H. (2005). Influence of growth phase on the essential oil composition of Hyptis suaveolens. Biochem. System. Ecol., 33: 275-285.

17. Pant, A.K.; Singh, A.K.; Mathela, C.S.; Parihar, R.; Dev, V.; Nerio, A.T.; Bottini, A.T. (1992). Essential oil from Hyptis suaveolens Poit. J. Essent. Oil Res., 4: 9-13.

18. Rasooli, I.; Abyaneh, M.R. (2004). Inhibition effects of Thyme oils on growth and aflatoxin production by Aspergillus parasiticus. Food Cont., 15: 479-483.

19. Rasooli, I.; Owlia, P. (2005). Chemoprevention by thyme oils of Aspergillus parasiticus growth and aflatoxin production. Phytochem., 66: 2851-2856.

20. Ricci, D.; Fraternale, D.; Giamperi, L.; Bucchini, A.; Epifano, F.; Burini, G.; Curini, M. (2005). Chemical composition, antimicrobial and antioxidant activity of the essential oil of Teucrium marum (Lamiaceae). J. Ethnopharm., 98: 195-200.

21. Santos, T.C.; Marques, M.S.; Menezes, I.A.C.; Dias, K.S.; Silva, A.B.L.; Mello, I.C.M.; Carvalho, A.C.S.; Cavalcanti, S.C.H.; Antoniolli, A.R.; Marçal, R.M. (2007). Antinociceptive effect and acute toxicity of the Hyptis suaveolens leaves aqueous extract on mice. Fitoterapia, 78: 333336.

22. Santos, T.S.; Marques, M.S.; Menezes, I.A.C.; Dias, K.S.; Silva, A.B.L.; Mello, I.C.M.; Carvalho, A.C.S.; Cavalcanti, S.C.H.; Antoniolli, A.R.; Marçal, R.M. (2007). Antinociceptive effect and acute toxicity of the Hyptis suaveolens leaves aqueous extract on mice. Fitoterapia, 78: 333336.

23. Sharma, N.; Tripathi, A. (2008). Effects of Citrus sinensis (L.) Osbeck epicarp essential oil on growth and morphogenesis of Aspergillus niger (L.) Van Tieghem. Microbiol. Res., 163: 337-344.

24. Sidibé, L.; Chalchat, J.C.; Garry, R.P.; Harama, M. (2001). Aromatic plants of Mali (III): Chemical composition of essential oils of two Hyptis species: H. suaveolens (L.) Poit. and H. spicigera Lam. J. Essent. Oil Res., 13: 55-57.

25. Souza, E.L.; Stamford, T.L.M.; Lima, E.O.; Trajano, V.N. (2007). Effectiveness of Origanum vulgare L. essential oil to inhibit the growth of food spoiling yeasts. Food Cont., 18: 409-413.

26. Van de Dool, H.; Kratz, D.J.A. (1963). A generalization of the retention index system including line temperature programmed gas liquid partition chromatography. J. Chromat., 11: 463-467.

27. Zollo, P.H.A.; Biyiti, L.; Tchoumbougnang, F.; Menut, C.; Lamaty, G.; Bouchet, P. (1998). Aromatic plants of tropical Central Africa. Part XXXII. Chemical composition and antifungal activity of thirteen essential oils from aromatic plants of Cameroon. Flav. Fragr. J., 13: $107-114$. 